\title{
Factors Affecting Firm Performance in manufacturing companies in Indonesia Stock Exchange
}

\author{
Agustin Ekadjaja $^{1}$, Andi Wijaya ${ }^{2}$, and Vernetta ${ }^{3}$ \\ ${ }^{1,2,3}$ Faculty of Economic and Business, Tarumanagara University, Jakarta, Indonesia \\ Email address: \\ agustine@fe.untar.ac.id,andiw@fe.untar.ac.id
}

\begin{abstract}
The aim in this reseach is to find empirical evidence to finding the influence between leverage, liquidity, growth, and firm size towards firm performance. The reseach method used was purposive sampling with a total sample of 44 firms listed on the Indonesian Stock Exchange (IDX). The subject of this reseach is all manufacture companies that are listed in Bursa Efek Indonesia for the period of 2017 until 2019. The type of data used is secondary data. Application that is used in this reseach is Eviews 11. This reseach shown that there are no significant influence between liquidity and firm age towards firm performance, there are positive significant influence between growth and firm size towards firm performance, and there is negative significant influence between leverage towards firm performance. The implication of this research is the need for high quality management that will encourage the firm to improve its performance in order to be able to determine the right strategies to be able to compete and then to maintain its sustainability.
\end{abstract}

Keywords: Firm Performance, Leverage, Liquidity, Growth, Firm age.

\begin{abstract}
Abstrak: Tujuan penelitian ini adalah mendapatkan bukti empiris mengenai pengaruh dari leverage, likuiditas, growth, dan ukuran perusahaan terhadap kinerja perusahaan. Sampel penelitian ini adalah 44 perusahan manufaktur selama tahun 2017 - 2019 yang diperoleh dengan menggunakan metode purposive sampling. Aplikasi yang digunakan untuk pengolahan data dalam penelitian ini adalah Eviews 11. Hasil dari penelitian ini menunjukkan bahwa likuiditas dan firm age memiliki pengaruh positif dan tidak signifikan terhadap kinerja perusahaan, growth dan ukuran perusahaan memiliki pengaruh positif dan signifikan terhadap kinerja perusahaan, dan leverage memiliki pengaruh negatif dan signifikan terhadap kinerja perusahaan. Implikasi dari penelitian ini adalah perlunya manajemen bermutu tinggi yang akan mendorong perusahaan untuk meningkatkan kinerjanya agar mampu menetapkan strategi-strategi yang tepat untuk dapat bersaing serta selanjutnya dapat mempertahankan kelangsungannya.
\end{abstract}

Kata Kunci: Kinerja Perusahaan, Leverage, Likuiditas, Growth, Firm age. 


\section{INTRODUCTION}

The current era of globalization has led to advances in science and technology, so that the world has experienced very rapid economic growth. This also encourages increasingly fierce competition in the global market. To deal with these conditions and circumstances, the company must see the opportunities and challenges that exist, so that the company can continue its activities normally and expand.

With the development of technology and information in today's business world, as well as dynamic economic developments, a company that can manage the company well is needed. In addition, there are prediction errors in the future which are a factor affecting the continuity of the company. This prediction error can cause loss of income or investment that has been invested in a company. Therefore, the company must have the right strategy so that it is able to maintain and improve its performance in every part in anticipation of increasingly fierce business competition.

Company is an institution or organization that provides goods or services for sale to the public. The company's goal in general is to maximize profits. Profit (profit) is the difference between the positive difference between revenue (price per unit multiple total quantity are sold) and the total cost (total fixed cost and variable cost (Bararuallo, 2019)).

A company can achieve its goals if the company has high quality management. High quality management is considered to be able to manage the company's resources and be able to carry out the company's operational activities well, so that the company is able to survive in an increasingly competitive competition. Because of this, it will encourage companies to improve their performance so that they can survive in the world of competition, always innovate, and be able to determine the right strategies to be able to compete, and then be able to maintain their continuity (Jonatan, 2018).

Good company performance indicates satisfactory results, so that it can be used as a basis for further developing the business. Conversely, poor company performance will make it more difficult for the company to maintain its existence. For this reason, company performance needs to be considered so that the company can maintain its continuity and expand.

\section{THEORITICAL REVIEW}

Pecking Order Theory. According to the Pecking Order Theory, companies with a high level of profit have a lower level of debt. There are hierarchical possibilities in picking financing sources, according to the pecking order hypothesis described by Smart, Megginson, and Gitman (Smart et al., 2004), namely: (1) Companies prefer to employ internal sources of finances or an internal perspective rather than external funding. (2) If external funding is required, the corporation will first choose the safest assets, such as the lowest risk debt, before moving on to the riskier debt, hybrid securities. (3) The company has a constant dividend policy, which means it will set a consistent dividend payment amount regardless of how much the firm gains or loses, and (4) In order to anticipate financial constraints. The corporation will employ an investment portfolio that is now available due to its consistent dividend policy and fluctuating profit rate. The pecking order theory explains the funding sequences and why companies with strong profit margins have low or optimal debt levels. Investment needs dictate the amount of money needed. 
Trade-Off Theory. There are several things that prevent companies from having large amounts of debt. One of the most important reasons is that the higher the amount of debt owed, the higher the possibility of the company going bankrupt. According to the trade-off theory expressed by Myers (Myers, 2001), p ompany will owe to the level of certain debt, in which the tax savings (tax shields) of additional $\mathrm{h}$ the debt is equal to the cost of financial difficulties (financial distress).

The cost of financial distress (financial distress) is a financial condition in trouble, crisis, or unhealthy conditions that occurred before the company went bankrupt. This occurs when the company fails or is unable to meet the needs of the debtor because it experiences insufficient and insufficient funds to run its business again (Riadi, 2018).

In determining the optimal capital structure, trade-off theory has several factors, namely the tax in determining the optimal capital structure, agency costs ( agency costs ) and the cost of financial difficulties ( financial distress), but in this case still have to maintain the assumption of market efficiency and symmetric information as benefits of using debt. The optimal level of debt can be achieved if the tax savings (tax shields) have reached the maximum amount against the cost of financial distress Within this trade off framework, managers will determine the capital structure between tax savings and the cost of financial distress. This happens because companies that have a high level of profitability will try to reduce the amount of tax by increasing their debt ratio, so that additional debt can reduce taxes (Utami NW, 6 Capital Structure Theory \& Its Application in Business, 2020) . However, in reality within the company, especially financial managers never think about this.

Signaling theory is one of the pillar theories in understanding financial management. In general, this theory is a signal that companies make to investors. This signal can manifest in various forms, both directly observable and one that requires more in-depth study to find out. Signals transmitted through corporations can be in the form of positive signals and negative signals (Fauziah, 2017).

This theory deals with information availability. Financial reports can be used to make decisions for investors, but besides that, an analysis of these financial statements is required. Signal theory is used to acquire information in the form of ROA, or rate of return on assets, and to determine how much profit may be made from the assets employed. As a result, a high ROA will be a good sign for investors. Because a high ROA indicates that a company's performance is strong, investors will want to put their money into equities. Stock prices will be high if the demand for shares is high, so that it will get high profitability and show good company prospects, and investors will be positively responsive to these signals. Thus, the company's performance is considered good by investors.

Firm Performance. Company performance is the overall success of the company in achieving the strategic goals that have been set by the company. These strategic goals are planned through the company's vision, mission and strategy. Company performance is the result of management activities in utilizing its resources. (Hery, 2017), performance measurement is an effort made to measure the level of success of business activities based on predetermined standards and criteria, as well as how the level of achievement of company success is in accordance with the target, so that irregularities that occur can be eliminated through a process of continuous improvement. 
Leverage. Leverage is the ratio used to measure the company's ability to fulfill all of the company's liabilities (debt) with total assets and or equity as collateral (Irfani, 2020). In general, this leverage ratio aims to measure a company's ability to meet its long-term and short-term financial obligations. This ratio is used to help measure the composition of capital that comes from debt or loans. In terms of analyzing company finances, this ratio plays an important role because it can provide information on the source of funds used to finance company operations or activities that come from own capital or debt.

Growth. Company growth can be achieved, if the company leader is able to make decisions to pursue growth as the main target in the company's strategy. Internal and external stakeholders in the company expect the company to grow, as strong growth is an indication of the company's development. From the perspective of an investor, a company's growth indicates that it is profitable, and investors will expect a return on their investment if the company's development is strong..

Firm age. Firm age indicates how strong a company is in facing competition and surviving in its industry. The longer the company has been established, it is expected that the company will have more superior performance marked by an increase in company assets and sales. In investment decisions, the age of the company is one of the factors in the assessment of investors because it provides information to investors how much investment opportunities the company can have. The amount of assets owned by the company indicates the company's ability to support the company's operations and business activities such as opportunities for business expansion (Rahmawati, 2017).

Firm Size. The size of the company shows that there are differences in the business risk of large and small companies. Company size can be shown by total assets, total sales, average sales level, and average total assets. Basically, company size is divided into three categories, namely large, medium, and small (Wati, 2019). The number of personnel engaged in the company to carry out firm operational operations, the number of assets owned by the firm, and the total revenue achieved by the firm are all metrics that can be used to measure the size of a firm. In a certain time period, as well as the number of outstanding shares.

\section{The Relationship between Variables}

The relationship of Leverage to Firm Performance. (Puspitaningtyas, 2015), Leverage has the potential to determine the level of risk the company must bear. The higher the level of corporate leverage, the heavier the financial burden faced by the company. It means, the higher the risk faced by the company. Debt that is too high can reduce excess cash flow that is in the company, as well as waste by management, so that leverage has an influence on company performance. Research conducted by Utami (Utami, 2018), (Dawar, 2014), (Mishra and Dasgupta, 2019), as well as Nardi and Anisa (Sunardi and Sasmita, 2019), shows that leverage has a negative effect and significant to company performance. The research conducted by (Suci and Nasib, 2019), shows that leverage has a negative and insignificant effect on company performance. 
The relationship of Liquidity to Firm Performance. In the investment management into current assets, one can say the greater the value of current assets available within the company, the more liquid a company. A company is called liquid when the company is able to fulfill its short-term obligations for the benefit of its day-to-day operations. Research conducted by (Astutik et al., Hutajulu, 2019), suggesting that liquidity has a positive and significant impact on the performance of the company. The research conducted by (Thaibah and Faisal, 2020), indicating that liquidity and without significant positive effect on company performance.

The relationship of Growth to Firm Performance. The growth of a company is very much tied to the continuity of the company and its profitability. Growth means change, and proactive change is essential in a dynamic business environment. In general, companies that have a high chance of growth indicate that the company has a good company performance. Research conducted by (Musah et al., 2019) and (Sunardi and Sasmita, 2019), show that growth has a positive and significant effect on company performance. The research conducted by (Jonatan, 2018) and (Megawati and Dermawan, 2019), shows that growth has no influence on company performance.

The relationship of Firm Age to Firm Performance. The age of the company can determine the amount of experience the company has. The longer the company has been established, it is expected that the company will have more superior performance marked by an increase in company assets and sales. Companies can carry out their routines in a structured and systematic manner, and carry out development as an innovation activity. According to research conducted by (Megawati and Dermawan, 2019) and (Dawar, 2014), it shows that firm age has negative and significant effect on company performance. The research conducted by (Haji and Mohd Ghazali, 2018) shows that firm age has a positive and insignificant effect on company performance.

The relationship of Firm Size to Firm Performance. According to Lela (Wati, 2019), the greater the size of the company, the better the technology and systems in a company and the ease with which management can use company assets that can boost the performance of a company. According to research conducted by (Megawati and Dermawan, 2019), it shows that firm size has a positive and significant effect on company performance. The research conducted by (Thaibah and Faisal, 2020), shows that firm size has a positive and insignificant effect on company performance.

Development of Empirical Hypothesis. Based on research, research conducted by Utami (Utami, 2018), (Dawar, 2014), (Mishra and Dasgupta, 2019), as well as (Sunardi \& Sasmita, 2019), shows that leverage has negative and significant influence on company performance. The research conducted by (Suci and Nasib, 2019), shows that leverage has a negative and insignificant effect on company performance.

H1: Leverage has a negative effect on company performance.

Research conducted by Erni, Retnosari, Ayunda, and Dinar (Astutik, Retnosari, Nilasari, \& Hutajulu, 2019), shows that liquidity has positive and significant effect on company 
performance. The research conducted by Thaibah and Faisal (Thaibah \& Faisal, 2020), indicating that liquidity and no significant positive effect on company performance.

H2: Liquidity has positive effect on company performance.

Research conducted by (Musah et al., 2019) and (Sunardi and Sasmita, 2019), show that growth has a positive and significant effect on company performance. Meanwhile, research conducted by (Jonatan, 2018) and (Megawati and Dermawan, 2019), shows that growth has no influence on company performance.

H3: Growth has a positive effect on company performance.

Research conducted by (Megawati and Dermawan, 2019) and (Dawar, 2014), shows that firm age has negative and significant effect on company performance. The research conducted by (Haji and Mohd Ghazali, 2018) shows that firm age has a positive and insignificant effect on company performance.

H4: Firm age has a positive effect on company performance.

Research conducted by (Megawati and Dermawan, 2019), which shows that company size has a positive and significant effect on company performance. The research conducted by (Thaibah and Faisal, 2020), shows that company size has positive and insignificant effect on company performance.

H5: Firm size has a positive effect on company performance.

The framework in this study can be seen in Figure 1

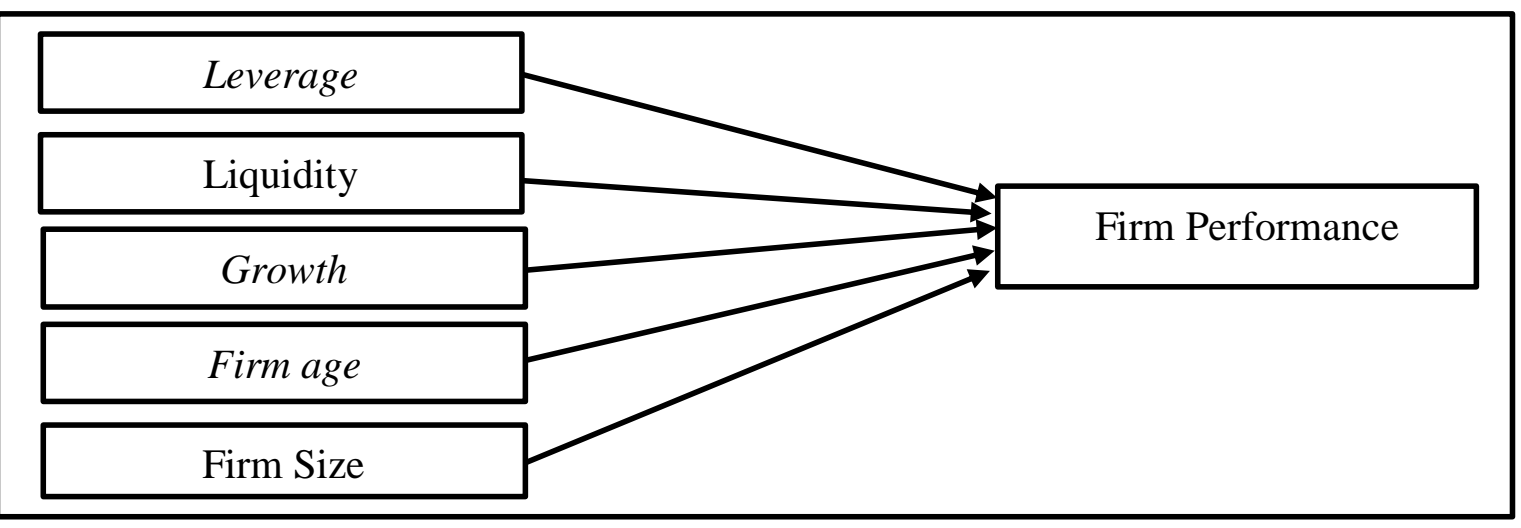

Figure 1. Research Model

\section{METHODS}

The research methodology is quantitative, employing secondary data gathered from the Indonesia Stock Exchange between 2017 and 2019. Purposive sampling was utilized to 
collect data for this investigation. Manufacturing companies listed on the Indonesia Stock Exchange between 2017 and 2019, manufacturing companies that publish their financial reports in Rupiah (IDR), manufacturing companies that publish complete annual financial reports and consecutively ending in December 31st are the sample selection criteria in this study and manufacturing companies that did not experience consecutive losses during the 2017-2019 period. Manufacturing companies listed on the Indonesia Stock Exchange for three years amounted to 534 data, which were then eliminated with 92 data. The total sample used in this study was 112 samples consisting of 44 companies with an observation period of three years, namely 2017 to 2019 .

The operational and measurement variables used are:

Table 1. Variables and Operational Measurement

\begin{tabular}{|c|c|c|c|}
\hline No. & Variable & Measurement & Scale \\
\hline 1. & $\begin{array}{l}\text { Dependent: } \\
\text { Firm Performance }(\mathrm{Y})\end{array}$ & $R O A=\frac{\text { Earning After Tax }}{\text { Total Asset }}$ & Ratio \\
\hline 2 & $\begin{array}{l}\text { Independent: } \\
\text { Leverage }\left(\mathrm{X}_{1}\right)\end{array}$ & $D E R=\frac{\text { Total Debt }}{\text { Total Equity }}$ & Ratio \\
\hline 3. & $\begin{array}{l}\text { Independent: } \\
\text { LIquidity }\left(\mathrm{X}_{2}\right)\end{array}$ & $C R=\frac{\text { Current Asset }}{\text { Current Liabilities }}$ & Ratio \\
\hline 4. & $\begin{array}{l}\text { Independent: } \\
\text { Growth }\left(\mathrm{X}_{3}\right)\end{array}$ & Sales Growth $=\frac{\text { Sales }_{t}-\text { Sales }_{t-1}}{\text { Sales }_{t-1}}$ & Ratio \\
\hline 5. & $\begin{array}{l}\text { Independent: } \\
\text { Firm Age (X4) }\end{array}$ & $\begin{array}{c}\text { AGE = Company Year In Sample - Company Year } \\
\text { Founded }\end{array}$ & Nomina \\
\hline 6. & $\begin{array}{l}\text { Independent: } \\
\text { Firm Size }\left(\mathrm{X}_{4}\right)\end{array}$ & Size $=\operatorname{Ln}($ Total Asset $)$ & Ratio \\
\hline
\end{tabular}

\section{RESULTS}

Classic assumption test. Furthermore, this study conducted a data assumption test, which expected the results to have value accuracy, consistency, and no bias. The normality test is carried out to determine and test whether the residual values that have been standardized in the regression model are normally distributed or not. This test is performed using the Jarque-Bera test to determine whether the data is normal or not. After doing 92 outliers, the result shows that the Jarque-Bera p-value is now 0.120529 . This value is greater than the 5\% significance level $(0.120529>0.05)$, so it can be said that the data after the outliers have been normally distributed. In the next test, namely the autocorrelation test with objective to test whether in the linear regression method there is a correlation between the confounding error in period $t$ with the confounding error in the previous period $(t-1)$ in the research regression model. If the Durbin-Watson value is between -2 and +2 , it means that the regression model is free from autocorrelation or there are no autocorrelation symptoms. In this study, the Durbin-Watson stat value is 0.345579 . This value means that it is between -2 and $+2(-2<0.345579<+2)$. From the value obtained, it can be concluded that there is no autocorrelation problem in the research model.

The next test is the heteroscedasticity test which aims to determine whether a variance of error in the observation is the same or not. In this study, using the white test to detect the presence or absence of symptoms of heteroscedasticity. The results obtained in this study, 
namely the probability value of Obs $* \mathrm{R}$-squared is 0.1032 , so this value is greater than the significance value of $5 \%(0.1032>0.05)$, so it can be concluded that the data in this study did not occur heteroscedasticity symptoms or the data was homoscedasticity.

Furthermore, a multicollinearity test was carried out which was used to determine whether there was a strong correlation or relationship between the independent variables in this study. In this test it can be seen that if the coefficient value between the independent variables in the study is smaller than 0.8 , it indicates that the research model does not have a multicollinearity problem or there are no independent variables that have a strong correlation. The results obtained in this study are the absence of a correlation coefficient value between independent variables which is greater than 0.8 , so it can be concluded that in this study there are no independent variables that have a strong correlation, and this study is free from multicollinearity problems.

$$
\begin{aligned}
& \mathrm{Y}=-0.257748-0.029068 \text { Leverage }+0.002115 \text { Liquidity }+0.051182 \text { growth }+ \\
& 0.000396 \text { Firm Age }+0.011092 \text { Company Size }+e
\end{aligned}
$$

The $t$ test results are carried out after all the classical assumption tests meet the requirements, and the results can be seen in the table below. 
Table 2. Results of Regression Analysis

Dependent Variable: Kinerja Perusahaan

Method: Panel EGLS (Cross-section random effects)

Date: 01/25/21 Time: 17:16

Sample: 20172019

Periods included: 3

Cross-sections included: 44

Total panel (unbalanced) observations: 112

Swamy and Arora estimator of component variances

\begin{tabular}{crrrr}
\hline \hline Variable & Coefficient & Std. Error & t-Statistic & Prob. \\
\hline \hline C & -0.257748 & 0.107297 & -2.402206 & 0.0180 \\
Leverage & -0.029068 & 0.010258 & -2.833808 & 0.0055 \\
Liquidity & 0.002115 & 0.003145 & 0.672486 & 0.5027 \\
Growth & 0.051182 & 0.018847 & 2.715733 & 0.0077 \\
Firm Age & 0.000396 & 0.000417 & 0.949115 & 0.3447 \\
Company Size & 0.011092 & 0.003662 & 3.028972 & 0.0031
\end{tabular}

\begin{tabular}{lrrr}
\hline \hline & Effects Specification & & \\
\hline \hline Cross-section random & & S.D. & Rho \\
Idiosyncratic random & & 0.034574 & 0.8527 \\
& & 0.014370 & 0.1473 \\
\hline \hline & Weighted Statistics & \\
Root MSE & 0.014147 & R-squared & 0.217146 \\
Mean dependent var & 0.015713 & Adjusted R-squared & 0.180219 \\
S.D. dependent var & 0.016037 & S.E. of regression & 0.014541 \\
Sum squared resid & 0.022414 & F-statistic & 5.880401 \\
Durbin-Watson stat & 1.930352 & Prob(F-statistic) & 0.000078 \\
\hline \hline & Unweighted Statistics & \\
\hline \hline R-squared & 0.249854 & Mean dependent var & 0.063863 \\
Sum squared resid & 0.144951 & Durbin-Watson stat & 0.298491 \\
\hline \hline
\end{tabular}

Source: Processed with Eviews version 11

Based on the regression results, it shows that the probability value of leverage is 0.0055 and the coefficient value is -0.029068 , so it can be said that the effect is negative and significant. High leverage can reduce company performance.

The second variable, namely liquidity, shows that the probability value is 0.5027 and the liquidity coefficient value is 0.002115 , so it can be said that the effect given is positive and insignificant. If liquidity is high, then the company's performance is also high or considered good.

The third variable, namely growth, shows that the probability value is 0.0077 and the growth coefficient value is 0.051182 , so it can be said that the influence given is positive and significant. If the growth is high or increasing, the company's performance is also high and considered good. 
The fourth variable, namely firm age, shows that the probability value is 0.3447 and the coefficient value is 0.000396 , so it can be said that the effect given is positive and insignificant. If the firm age is getting longer, the company's performance is also considered to be better.

The fifth variable, namely company size, shows that the probability value is 0.0031 and the coefficient value is 0.011092 , so it can be said that the influence given is positive and significant. If the size of the company is getting bigger, the company's performance is also high or considered good.

In the F test, based on the results obtained, it can be seen in the F-statistical probability value. The results obtained in this study indicate that the F-statistical probability value is smaller than the $5 \%$ significance level $(0.000078<0.05)$, it can be concluded that the leverage, liquidity, growth company size and firm age variables simultaneously have a significant effect on company performance variables. The research also shows that the adjusted $\mathrm{R}$ square value in the regression model is 0.180219 . The results obtained indicate that the variables of leverage, liquidity, growth, company size and firm age are only able to explain the company's performance variables by $18 \%$, and the remaining $85 \%$ will be explained by other variables outside the model.

This study was conducted to determine the effect of leverage, liquidity, growth, company size and firm age as independent variables on company performance as the dependent variable. This research shows that if the leverage increases, the company's performance will be smaller. This means that companies that have a high level of leverage can reduce the company's performance. The results of this study are not in line with the research conducted by (Azzahra, 2019), which shows that leverage has a negative and insignificant effect on a business's performance. In his research, he stated that debt that is too high potentially reducing the excess cash flow that is in the company and lower their inventory, which means that management does not work efficiently. Being overleveraged typically leads to a bigger potential risk, which as a result investors will hesitate to invest. However, this research is in line with the research conducted by (Utami, 2018), (Varun, 2014), (Sibanjan and Ranjan, 2019), and (Nardi and Anisa, 2019), which show that leverage has a negative and significant effect on company performance.

In research conducted by Utami, it shows that, a lot of debt, it will give a bad risk to its financial performance and decrease their ability to meet its obligations. However, if the level of debt is good, the company will be efficient in increasing profits because the additional existing capital can increase operations and investor confidence. This result is under the trade-off theory, which states that the use of debt can increase the firm's value to the optimal leverage limit because by using debt, it will cause interest costs which will be a tax deduction so that companies with a high probability level will trying to reduce the amount of tax by increasing the debt ratio, and afterward the use of the debt will reduce the value of the company because the use of debt after optimal leverage can also cause a greater bankruptcy cost. Thus, companies need to consider the capital structure between tax savings and the cost of financial hardship.

This study shows that if liquidity increases, the company's performance will also increase. These results indicate that companies with high liquidity are considered to have good performance because they are able to meet their short-term obligations, but do not guarantee that the company is able to pay their short-term debts on time. The results of this study are not in line with the research conducted by this study in line with research 
conducted by (Erni et al., 2019) which shows that liquidity has a positive and significant effect on company performance. The results of his research state that when a business has a good current ratio, they are able to pay high cash dividends to investors, as a result, the company has additional capital to fund its operations and can increase the company's profit growth. Meaning that their performance is considered good since the company can measure its financial performance effectively and able to meet its short-term obligations which correspondingly increase its profit growth.

However, this research is in line with research conducted by (Thaibah and Faisal, 2020) which shows that liquidity has a positive and insignificant effect on firm performance. The results of his research state that, the greater the liquidity, the greater the level of financial performance, but this effect is not significant on financial performance. Companies that are unable to meet their short-term obligations may pose a risk to their survival because their operational needs cannot run smoothly. Thus, the company does not have a good performance in carrying out its operational activities, so that it is unable to fulfill its shortterm obligations which can interfere with its survival.

This research shows that in companies that are growing, the performance of a company will also be considered to be better because a growing company will pay attention to its financial performance. The results of this study are not in line with the research conducted by this study in line with research conducted by (Erni et al., 2019) which shows that liquidity has a positive and significant effect on company performance. The results of his research state that when a business has a good current ratio, they are able to pay high cash dividends to investors, as a result, the company has additional capital to fund its operations and can increase the company's profit growth. Meaning that their performance is considered good since the company can measure its financial performance effectively and able to meet its short-term obligations which correspondingly increase its profit growth.

However, this research is in line with research conducted by (Thaibah and Faisal, 2020) which shows that liquidity has a positive and insignificant effect on firm performance. The results of his research state that, the greater the liquidity, the greater the level of financial performance, but this effect is not significant on financial performance. Companies that are unable to meet their short-term obligations may pose a risk to their survival because their operational needs cannot run smoothly. Thus, the company does not have a good performance in carrying out its operational activities, so that it is unable to fulfill its shortterm obligations which can interfere with its survival.

This result is in accordance with the pecking order theory, which describes funding sequences in which companies will choose to use debt rather than issue equity. Companies that are growing will prefer funding that comes from debt rather than issuing shares. This is because, if the company grows, it will cause higher information asymmetry. This condition explains that debt has a lower risk than issuing new shares. Therefore, it can be assumed that the company aims to maximize the welfare of shareholders, so that this can be seen from the company's growth.

This study shows that if the firm age increases, the company's performance will also increase. Senior companies are considered to have more experience and knowledge and carry out their routines in a more systematic and structured manner. In addition, senior companies usually carry out development as an innovative activity and have many ideas in creating new products, so that by having this experience, it is easier for companies to improve overall company performance. However, this does not have a significant effect, 
because there are several younger companies that have better performance than senior companies, because senior companies lose the courage to take risks and try new things, so that this causes the company to lose its competitive advantage, and ultimately the company's performance has decreased.

This study shows that if company size increases, the company's performance will also increase. The results of this study are not in line with the research conducted. This study is in line with the research conducted by (Megawati and Darmawan, 2019), which shows that firm size has a positive and significant effect on company performance. The results of his research state that a larger company is considered to be superior in producing good performance than a smaller company, the company can more easily adapt to pressures and changes in market developments. If the performance of a company is good, it will reflect the company's performance in managing existing resources effectively and efficiently to earn profits, the better the company's performance, the more trusted the company will be in meeting the expectations of consumers and stakeholders.

However, this study is in line with research conducted by (Thaibah and Faisal, 2020), which shows that the company's size has a positive but insignificant effect on company performance. In this study, it is explained that the greater the size of the company, the greater the level of financial performance, but this effect is not significant on financial performance. A large company means that the greater the assets owned, the more capital invested, the more sales, the greater the company is known to the public. Large companies generally have good performance. Large companies are considered to have a better chance of obtaining credit from financial institutions, thus indicating that large companies have a low probability of bankruptcy. This result is in accordance with the signaling theory, which explains that large companies provide favorable signals to investors.

\section{CONCLUSION}

The performance of manufacturing companies listed on the Indonesia Stock Exchange from 2017 to 2019 shows that leverage, liquidity, growth, firm age, and company size are not fully influenced by company performance; there may be other variables that can explain and influence company performance, according to the test results in this study.

The first independent variable in this study, namely leverage has a negative and significant effect on company performance, this indicates that if a company with a high level of debt has a high risk of failing to fulfill its obligations, it causes a decrease in the company's performance. Previous research conducted by (Utami, 2018), (Varun, 2014), (Sibanjan and Ranjan, 2019), and (Nardi and Anisa, 2019), showed the same results that leverage has a negative and significant effect on company performance.

The second independent variable in this study is liquidity which has a positive and insignificant effect on company performance. This shows that if the company has high liquidity, then the level of performance of the company will also be high. Companies with high liquidity are considered to have good performance because they are able to meet their short-term obligations, but this does not guarantee that the company is able to pay their short-term debts on time. Previous research conducted by (Thaibah and Faisal, 2020) showed the same results that liquidity had a positive and insignificant effect on company performance. 
The third independent variable in this study is growth which affects significantly on the company performance. This shows that if the company experiences an increase in growth, it will cause an increase in company performance. Companies that are increasingly growing will experience an increase in their performance, where a good company performance will have favorable job prospects, so that the company can make a profit. Previous research conducted by (Mohammed et al., 2019), and (Nardi and Anisa, 2019) showed the same results that growth has positive and significant effect on company performance.

The fourth independent variable in this study, namely firm age, which has a positive and insignificant effect on company performance. This shows that if the company has high the firm age is getting longer, the company's performance is also considered to be better.

The fifth independent variable in this study, namely company size have a significant effect on company performance. This shows that the size of a large company is considered to have good company performance. However, small companies with good management have better performance than some large companies, so company size does not have a significant effect on company performance. Previous research conducted by (Thaibah and Faisal, 2020), shows the same results that company size has a positive and insignificant effect on company performance.

There are several limitations in this study, namely the sample in this study is only for a three-year period, namely 2017-2019, so that the research conducted does not reflect the overall condition but only partially, the population in this study does not reflect all companies listed on the Indonesia Stock Exchange, because the research conducted only focuses on companies in the manufacturing industry.

Based on the above limitations, there are several suggestions that can be given for further research, namely further research is expected to expand the sample and increase the research period, further research is expected to test other independent variables besides the independent variables that have been tested in this study. such as job satisfaction, work motivation, personality, skills skills, loyalty, and other variables that might explain the company's performance variables, and further research is expected to be able to select other industries as samples in their research such as service companies, non-financial companies and so on, so that not only selecting samples from manufacturing companies.

\section{REFERENCES}

Astutik, E. P., Retnosari, Nilasari, A. P., dan Hutajulu, D. M. (2019). Analisis Pengaruh Rasio Likuiditas, Solvabilitas dan Profitabiltas Terhadap Kinerja Keuangan Perusahaan Manufaktur. Prosiding SEMINAR NASIONAL DAN CALL FOR PAPERS, 103-118.

Bararuallo, F. (2019). Pengantar Bisnis. Jakarta: Universitas Katolik Indonesia Atma Jaya. Dawar, V. (2014). Agency Theory, Capital Structure and firm performance: some Indian Evidence. Managerial Finance, 40, 1190-1206.

Fauziah, F. (2017). Kesehatan Bank, Kebijakan Dividen, dan Nilai Perusahaan Teori dan Kajian Empiris. Samarinda: RV Pustaka Horizon. 
Haji, A. A., and Mohd Ghazali, N. A. (2018). The Role Of Intangible Assets and Liailities in Firm Performance: Empirical Evidence. Journal of Applied Accounting Reseach, $19,42-59$.

Hery. (2017). Balanced Scorecard For Business. Jakarta: Grasindo.

Irfani, A. S. (2020). Manajemen Keuangan dan Bisnis Teori dan Aplikasi. Jakrta: PT. Gramedia Pustaka Utama.

Jonatan, I. B. (2018). Pengaruh Struktur Modal, Ukuran Perusahaan, Pertumbuhan Perusahaan Terhadap Kinerja Perusahaan Pada Perusahaan Non Keuangan Dengan Menggunakan Dupont System. Jurnal Muara Ilmu Ekonomi dan Bisnis, 2, 424-432.

Megawati, dan Dermawan, E. S. (2019). Analisis Pengaruh Firm Size, Firm Age, Leverage, Dan Growth Terhadap Kinerja Perusahaan. Jurnal Multiparadigma Akuntansi, I, 666674.

Mishra, S, and Dasgupta, R. (2019). Cross-impact of leverage and firm performance: developed vc frontier bank-based economies. Managerial Finance, 45, 982-1000.

Musah, M., Kong, Y., Antwi, S. K., Donkor, M., Quansah, P. E., and Obeng, A. F. (2019). A study into growth and firms' financial performance: Evidence from the Ghana Stock Exchange (GSE). International Journal of Multidisciplinary Research and Development, $45-53$.

Myers, S. C. (2001). Capital Structure. The Journal of Economic Perspectives, 15, 81-102.

Puspitaningtyas, Z. (2015). Prediksi Risiko Investasi Saham. (A. Giyanto, Ed.) Yogyakarta: Griya Pandiva.

Rahmawati, S. (2017). Konflik Keagenan dan Tata Kelola Perusahaan di Indonesia. Banda Aceh: Syiah Kuala University Press.

Smart, S. B., Megginson, W. L., and Gitman, L. J. (2004). Corporate Finance. South Western: Mason.

Suci, A., dan Nasib. (2019). Pengaruh Firm Size dan Leverage Ratio Terhadap Kinerja Keuangan pada Perusahaan Pertambangan. JWEM STIE MIKROSKIL, 9, 2622-6421.

Sunardi, N., dan Sasmita, A. S. (2019, 1 2). Pengaruh Likuiditas, leverage, dan Growth Terhadap Kinerja Industri Makanan dan Minuman yang Tercatat di Indonesia Stock Exchange Selama Periode 2011-2015. Jurnal Sekuritas, 2.

Thaibah, dan Faisal. (2020). Pengaruh Kecukupan Modal, Ukuran Bank, Biaya Operasional dan Likuiditas Terhadap Kinerja Keuangan Perbankan yang Terdaftar Di Bursa Efek Indonesia. Jurnal Ilmiah Mahasiswa Ekonomi Manajemen, 5, 294-309.

Utami, N. (2018). Pengaruh Risiko Likuiditas dan Leverage Terhadap Kinerja Bank yang terdaftar Di Bursa Efek Indonesia Periode 2010-2015. BALANCE, 15, 189-209.

Utami, N. W. (2020). 6 Teori Struktur Modal \& Penerapannya dalam Bisnis. Retrieved from https://www.jurnal.id/id/blog/2018-penjelasan-lengkap-6-teori-struktur-modal/

Wati, L. N. (2019). Model Corporate Social Responsibility (CSR). Jawa Timur: Myria Publisher. 